\title{
India establishes countrywide satellite computerized database
}

New Delhi

A NATIONWIDE satellite-based computerized information network is being set up by the Indian government to provide its planners with instant access to information needed for decision-making and monitoring of development programmes.

By the end of this year, government offices in each of the 430 districts, the 22 state capitals and major cities will be hooked into a vast information network that will move data from virtually any part of the country to the offices of ministers and their secretaries in central and state governments.

The man behind the $\$ 70$ million project is Dr N. Seshagiri, director of the National Information Centre (NIC) created by Mrs Indira Gandhi in 1977. NIC now services 62 central government departments in New Delhi through a cable and VHF network linking computer terminals in individual departments with NIC's 170/720 computer, the biggest in India, which stores some 200 databases covering crucial sectors of the economy.

NIC's computerized management information has already proved valuable. For example, the performance of power plants is monitored daily, trade figures are updated every day and performance indices of all public-sector undertakings are regularly tracked. The 1987 budget, to be presented this month by the Prime Minister, Mr Rajiv Gandhi, will also be based on data drawn from NIC's computer. According to Seshagiri, NIC's services are now being extended to cover the whole of India with the help of the satellite.

The new project will ensure the creation of district databases on health, agriculture, rural development, employment and other relevant social and economic matters; they will be stored in locally made microcomputers in the offices of district collectors. Four large mainframe computers (NEC-1000) imported from Japan have already been installed in Delhi, Pune, Bhubaneswar and Hyderabad to store databases from the regions.

Within the next two months, superminicomputers will be installed in the offices of the chief secretaries in all the state capitals. These computers are being made by the state-owned Electronic Corporation of India under licence from the Control Data Corporation of the United States.

Except for the imported master Earth Station at New Delhi, all other computers in the network will be linked to the satellite by micro Earth stations and two-way roof-top antennas. The first batch of 120 micro Earth station antenna systems are being imported from the Equatorial Corporation in the United States. The rest will be supplied by Indian Telephone Industries in Bangalore, which has purchased the technology from the US company.

According to Seshagiri, the network will become operational in May, using a leased Intelsat transponder over the Indian Ocean. But NIC hopes to get a loan from the World Bank to acquire and launch its own satellite, Nicsat, in collaboration with the Indian Space Department, by 1990 . Nicsat will operate in the $\mathrm{Ka}$ band $(20 \mathrm{GHz})$, making possible the use of still smaller (50-cm diameter) dish antennas costing less than $\$ 2,000$ each.

Seshagiri believes India is the first country to establish a satellite-based information network dedicated to government decision-making and to toning up the sag-

\section{Teacher union issues London}

The National Union of Teachers (NUT), the negotiating body for most of Britain's schoolteachers, has published guidelines on AIDS (acquired immune deficiency syndrome) to "reassure members and dispel myths about the spread of the disease".

According to the NUT deputy general secretary Doug McAvoy: "It is vital that teachers know the facts. The NUT's notes on AIDS should reassure members that they need not worry about contracting AIDS in their contact with pupils." Teachers should be entrusted with confidential information on children's health, and confidentiality must be maintained to protect children from victimization as a result of unfounded fears of infection.

The guidance notes, to be distributed to

\section{AIDS guidelines}

the NUT's 650 local associations and branches, focus on homosexual and bisexual men, drug addicts who share needles, and haemophiliacs as the 'risk groups'.

Evidence shows, says the union, that children who carry human immunodeficiency virus pose no risk to other children or adults in a normal school environment and should attend school normally.

The union says: "None of the identified cases of HIV infection in this country or the United States is known to have been transbeen spread through casual personal contact. There is no reason for teachers to be concerned about handling objects used by an infected person and no need for separate toilets or crockery and cutlery".

Bill Johnstone mitted in a school setting, nor has the virus
Schools wooed for science teaching

\section{London}

THE promotion of science in British schools was given a boost last week with the launch of two programmes to attract unconfident teachers to science and to encourage them to include it in their curriculum.

The first is a comprehensive basic science teaching kit in the form of teachers' notes and colourful learning cards for children. The kit, prepared by the British Gas Corporation, and designed for young children, will outline the basic concepts of air, flight, forces, heat, water and 'ourselves'.

Another project is designed to promote education in science using information stored on a computer database. The project, which will be funded by the Department of Trade and Industry until April next year, allows teachers with microcomputers and modems to 'dial' into the system to obtain teaching aids.

The system, called the National Educational Resources Information Service, will have about 500,000 'resources' listed on the database by 1988 . The data will be housed in the computer of the Open University.

Bill Johnstone

ging administrative machinery. "Some 10,000 government-aided projects are being implemented in various districts, but central ministers have no fast means of monitoring the time and cost overruns", says Seshagiri. He says the cost of the network will be recovered several times over by better management of multimillion dollar development projects that now languish because of delays in decisionmaking.

States that were initially hesitant to share information with the centre have joined the network after an assurance from NIC that the autonomy of the federal structure will be respected. No data relating to police or security matters or that violates the privacy of individuals or organizations will be collected. Seshagiri says 85 per cent of information in databases will be open to officials; the remaining 15 per cent will be secure and available only to specially authorized personnel. About 1,300 government officers have been trained in database creation and NIC hopes to train several hundred more soon.

At the same time, the state-owned Computer Maintenance Corporation of India is setting up a network called Indonet for public use. It provides computer booths throughout the country that can be used by, among others, small businesses unable to afford their own computers. The fourth-generation IBM computers at Bombay, Hyderabad, Delhi, Calcutta and Madras that form Indonet will eventually be linked via satellite and expanded to cover 35 cities.

K.S. Jayaraman 